\title{
THE EXPECTED TENDENCIES OF THE GDP OF THE THREE LEADING GLOBAL ECONOMIES IN 2020: IS A REBALANCE OF (GEO)ECONOMIC POWER ARRIVING?
}

\author{
Goran Nikolic ${ }^{* 1}$ and Predrag Petrovic ${ }^{2}$ \\ ${ }^{1}$ Institute of European Studies, Belgrade, The Republic of Serbia \\ ${ }^{2}$ Institute of Social Sciences, Center for Economic Research, Belgrade, The Republic of Serbia
}

The International Monetary Fund (IMF) forecasts a gradual slowdown in the, otherwise strong, growth of the Chinese economy in the first half of the 2020s, and the anemic growth of the Western economies: the US and, especially, the EU27. Given the practical (and symbolic) importance of reaching the number one economy' status, the primary objective of the paper is to estimate the GDP (and the GDP PPP) of the observed economies over the next decade. The main contribution and finding of this paper is the estimation of future GDP trends for the US, China and the EU27 in the period 2025-30, based on the previous trends and the IMF 2020-24 projections. China's economy will become globally leading in 2029-2030. The basic research hypothesis is proven, given the fact that a change in the global economic position implies significant geopolitical consequences. Namely, while the US will almost certainly remain the leading global power in the 2020s, with the EU still continuing to focus on itself, China's economic growth will have rising global consequences, fueling the move towards the dispersion of authority. This conclusion is in line with the claims of the majority of the relevant authors who emphasize the increasingly limited possibility of the US unilateral actions.

Keywords: GDP, economic growth, China, the US, EU27, global order

JEL Classification: F2, F50, 047

\section{INTRODUCTION}

In academic circles, the question has increasingly been arising as to when China's 'famous' overtaking of the US might occur when the overall GDP measured by market rates, which is still considered as the most

* Correspondence to: G. Nikolic, Institute of European Studies, Trg Nikole Pasica 11, 11000 Belgrade, The Republic of Serbia; gorandrnikolic@gmail.com important indicator of the overall size of the economy, is concerned. According to the IMF projections (2019), China's economic growth will slightly slow down in the period 2020-24, and in the last years of that period, its growth will be $5.5 \%$. At the same time, the economic growth of the EU27 and the US will be substantially lower $(1.5 \%$ and $1.6 \%$, respectively, in 2024, after slowing down over the observed period). Consequently, these tendencies will lead to the further 
narrowing of the differences between the GDPs of the observed economies.

The subject of the research study is the three largest economies in the world: the US, the EU27 and China (whose sizes were expressed through the GDP or the GDP PPP), i.e. the effects of changing the relative weights of these economies on the future global geopolitical constellation. This has very important implications, since the status of the world's largest economy has, as a rule and with some time lag, led to the leading role of that same country globally. Specifically, there are the indicative examples of the strong economic rise of Great Britain during the 15th and 16th centuries, and of the US since the mid-19th century, followed by the global domination (military, diplomatic, cultural, and economic) of the two countries.

The main objective of the paper is to estimate the GDP (and the GDP PPP - Purchasing Power Parity) for the world's three leading economies by 2030. This will be done based upon the available data on the current GDP trends, the IMF projections, and the authors' calculations for the GDP of these three leading economies, with the aim of possibly determining the year when China's economy might become the world's largest. So, the goal of the paper is to show the great - i.e. transformative - significance of the current and the expected (extremely unequal) economic growth of the world's largest economies by analyzing and assessing the dynamics of their GDPs and relying on the theoretical assumptions related to the geopolitical rise and possible global domination by the countries with the largest GDP in the world.

Pursuant to the defined subject matter and the set goal of the research study, the following hypothesis will be tested in the paper:

$\mathrm{H}$ : Measured by market exchange rates, China's economy will surpass the economy of the US at the end of 2020s and become the largest global economy.

The concrete quantitative methodological approach applied in testing the set hypothesis is presented in the third part of the paper. In the paper, a qualitative methodology and a quantitative methodology are applied. The application of the qualitative methodology reflects in referring to the related, mainly foreign studies (which are based on theoretical generalizations and the experiences of the scientists who have dealt with the same or a similar problem) in order to create theoretical support for the application of the quantitative methodology (which serves to test the main hypothesis). The analysis and synthesis, induction and deduction methods, and especially the comparison method, are applied. An emphasis is placed on the quantitative methodology, i.e. on projecting the GDP trends of the three observed economies, all the data being taken from the IMF database (IMF, 2019).

In the second part of the paper, the studies that deal with virtually the same topic, but virtually ignore the analysis of the EU27, which, as a part of the West is considered to be an important element of the overall (geo)economic equation, will be presented. Then, the methodology applied will be explained. In the next three parts of the paper, the basic economic performances and long-term (geo) economic perspectives of the three largest economies in the world, namely the EU27, the US and China, are discussed. This is followed by the Conclusion, in which a possible scenario for the risky balancing of the leading and the growing power (the practical "challenger") is indicated, which historically often led to military confrontations, all this bearing in mind the crucial significance of economic strength for projecting geopolitical power.

\section{LITERATURE REVIEW}

With China's strong economic rise over the four decades, an increasing number of papers have emerged, showing that this economy is about to become the largest in the world. According to a forecast by the economists in HSBC Holdings Plc given in a study covering the world's 75 largest economies, China will become the leading global economy by 2030, with a GDP of \$26 billion. Moreover, the Chinese economy will also continue to make the 
largest contribution to global growth throughout the 2020s (Kennedy, 2018).

The OECD $(2018,8)$ projects a continued slowdown in the real GDP growth globally, but the growth of developing countries will nevertheless remain significantly faster than that in industrialized countries. Consequently, the OECD's share in world production (i.e. the GDP), which already fell from 72\% in 2000 to just below 54\% in 2019 (in Purchasing Power Parity), will decline to $43 \%$ by 2060 . China's share in world production will peak during the 2030s, reaching around 27\%, whereas India's share will continue to grow. From the point of view of each individual country, the share of both countries will be significantly above the share of the US.

The study by Price Waterhouse Coopers (PwC, 2019, 19-20) predicts that the Chinese economy will have grown larger than that of the US before 2030, largely due to the narrowing of the productivity gap between the two countries and given the fact that China's population is four times larger. In terms of Purchasing Power Parity, China has been the world's largest economy since 2014 (followed by the US, the EU27, and India). The strong growth of China and India will further reduce the share of the EU27 in the world GDP. It is projected that the share of this economic entity in the global economy (expressed in the PPP) will steadily decline to the modest $9 \%$ in 2050 .

The projections of the CEBR $(2019,75)$ indicate that China might become the world's largest economy a little later, i.e. in 2033, overtaking the United States with modern technologies as the engine of growth. This estimate is based on the relatively moderate growth rates, which are expected to average $5.4 \%$ in the period $2019-24,5.2 \%$ in the period $2024-29$, and $4.3 \%$ in the period $2029-34$.

On the other hand, C. Huang (2020) emphasizes the fact that the perception that China is the number two global power and on the path to becoming number one is based on the two questionable assumptions that Chinese strong growth will continue and that the GDP can be equated with the power of the country. This author states that the growth has slowed steadily since the peak of 2007, that there are doubts about the accuracy of the data, and that there are warnings that economic growth might stabilize at the US level, in which case China would never catch up with the US. Specifically, the GDP growth is closely linked to the government-led real estate bubbles, speculation and capital investment, which has resulted in excess capacities, as well as an increase in non-performing loans (NPLs). Even if China's GDP outperforms America's, it does not mean that China will be as economically powerful and wealthy as the US. In fact, the data about the total GDP do not refer to the wellbeing of individuals - the GDP per capita is usually used for this purpose. According to the IMF (2019) data, China's GDP per capita in 2019 was with the US $\$ 10,246$, which is more than six times less than that of America's, primarily due to the higher productivity of US workers.

\section{METHODOLOGY}

The applied methodology first takes the IMF (2019) projections of the GDP of the three mentioned economies, whose estimated values are given in current dollars, throughout the year 2024. Then, it starts with the basic assumption (assumption number one) that nominal GDP growth in 2024 will continue over the next five - or six - years until 2029-30 (the fact that Chinese nominal GDP growth in that year will be lower than the average of 2020-24 is especially important). Given the fact that, in addition to real GDP growth, nominal GDP growth incorporates the GDP deflator and possible exchange rate fluctuations, this approach might be methodologically acceptable. However, given the fact that a faster-growing economy generally tends to have greater variations in nominal and real GDPs in absolute terms, an alternative approach (assumption number two) is applied, where China's nominal growth rate is significantly knocked down (by an average of $0.7 \%$ ) in the period after 2024, simultaneously leaving the figures for the US and the EU27 unchanged. An even more conservative approach (assumption number three) is then applied, where China's nominal (and actually real) GDP growth after 2024 is phased out by the additional $0.2 \%$ every year all the way to 2030 (the 
year in which China's real GDP growth is estimated at a relatively modest $4.3 \%$ ). For the EU27, i.e. the EU without the UK, the GDP data are calculated by simply subtracting the UK's GDP, after which the earlier principle - retaining nominal growth from the last projected year for the EU by the IMF - is then applied, which can be considered as an optimistic assumption for the EU.

Based on the above IMF projections and the authors' additional calculations for the three observed economies, including the calculations of their shares in the world GDP (at current dollars and in Purchasing Power Parity international dollars), the obtained results are practically in line with much of the previously cited literature. Actually, starting from Assumption 1 (the constant nominal growth of China's GDP of 8.1\% after 2024), Assumption 2 (the constant nominal growth of China's GDP from 7.4\% after 2024) and Assumption 3 (the constant decrease of China's nominal GDP growth by $0.2 \%, 0.4 \%, 0.6 \%$, $0.8 \%, 1 \%$ and $1.2 \%$ by $2025-2030$, respectively, being relatively modest $6.9 \%$ in the last observed year), then in 2029 (Assumption 1), or in 2030 (Assumptions 2 and 3), China's GDP would surpass the GDP of the
US. When the EU27 is concerned, it would already happen by the year 2022 (Figure 1). The conservative assumptions (namely Assumptions 2 and 3) result in a marginally different result: the shift of the catch-up year to 2030, which indicates the fact that the trend of the strong growth of the Chinese economy and its rise to the pedestal of the world can hardly be stopped.

According to Purchasing Power Parity, China's GDP will roughly equal the cumulative GDP for the two observed western economies $(93 \%$ higher than that of the US and 113\% higher than the EU27's GDP) in 2030, under the basic assumption (Assumption 1). The result is only slightly less impressive considering the other two assumptions (Figure 2).

Additionally, China's GDP data seem slightly better after the modifications in the fourth Chinese economic census. Specifically, in November 2019, China revised its GDP for 2018, based upon the results of the new national census. Consequently, the GDP increased by $2.1 \%$ in 2018 , as the size of the economy is thought to be undervalued in the service sector, due to the recent rapid transition to the digital and services sectors (Tang, 2019). This revision was not included in our

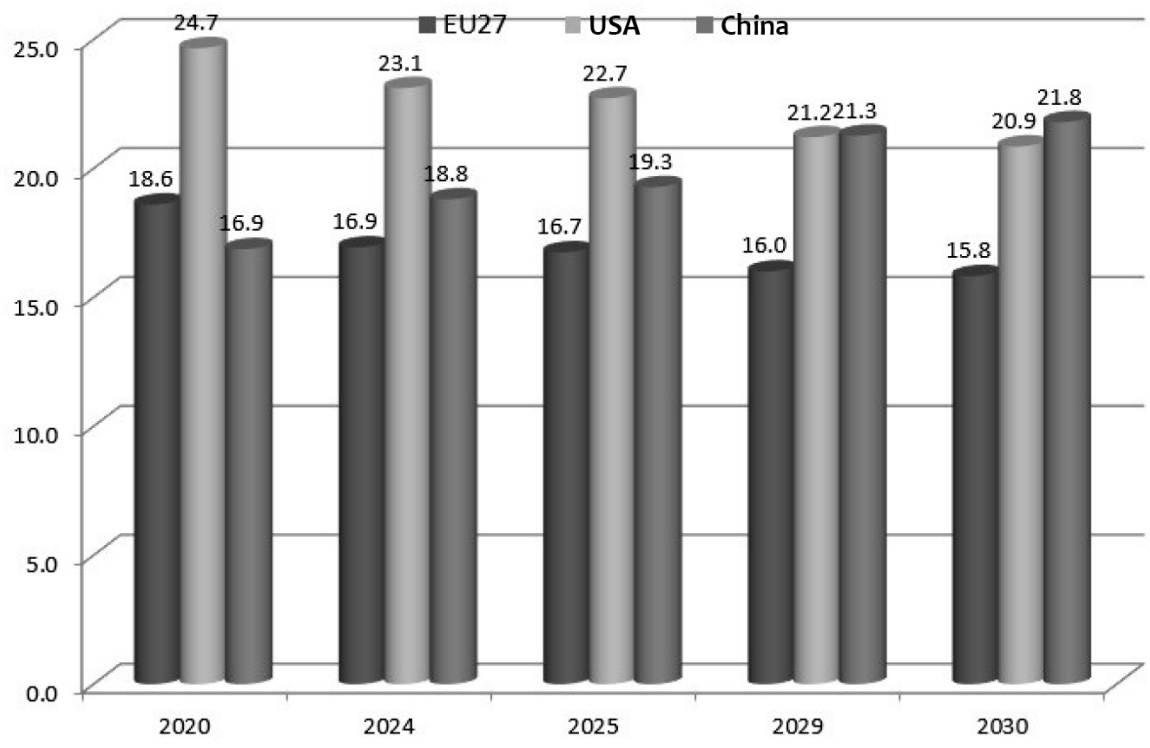

Figure 1 The share of the leading economies in the world GDP

Source: Authors, based on the IMF, 2019 


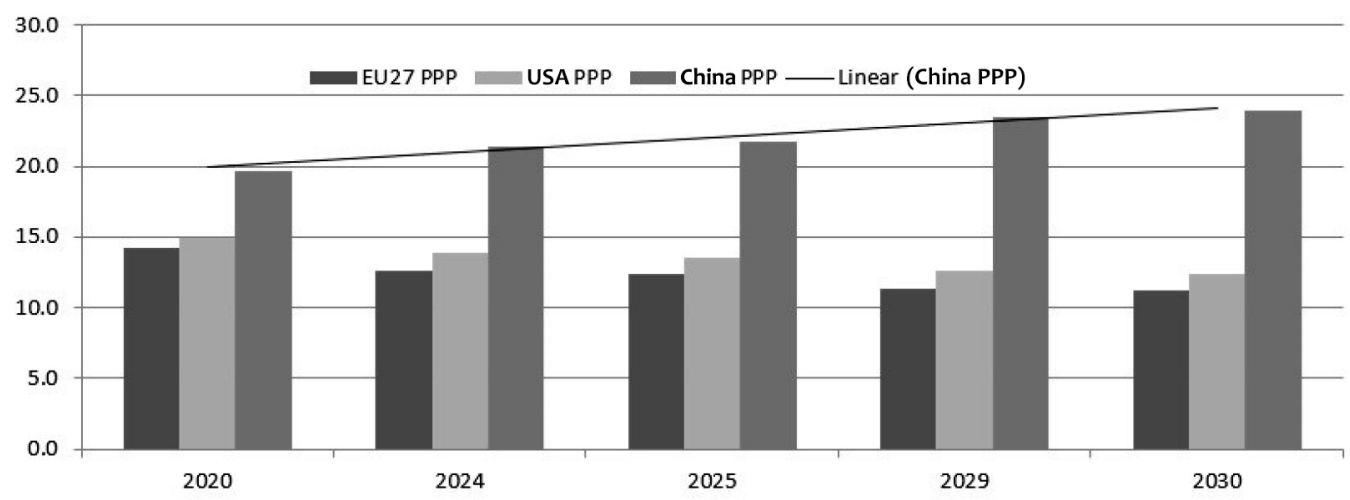

Figure 2 The Share of GDP of the US, China, and the EU27 in the world GDP, expressed in Purchasing Power Parity (PPP)

Source: Authors, based on the IMF, 2019

projections, and this figure could be significantly higher than the expected fall in the GDP due to the Coronavirus. Associated with this, the announced more expansive fiscal and monetary policy should give effects. Namely, after a significant reduction in GDP growth in the first quarter of 2020 (by half or by one-third), the annualized decline in GDP growth will be limited to $0.5-1$ percentage points, which would mean a still high growth of 5\% to 5.5\% in 2020 (June, 2020). In addition, there are minimal changes in the last IMF (January) Report (2020), looking at the estimated GDP growth rates of the US and the Eurozone (a 0.1\% decrease in 2020) and China (a 0.2\% increase in 2020, and a decline of $0.1 \%$ in 2021).

Interestingly, for the first year for which there are comparable data (i.e. for the year 1980), in terms of the PPP, the EU27 economy is as much as one-third larger than the US economy (34.2\%, to be more precise), while in the same year, the GDP at market rates is approximately equal (the EU has a GDP lower by a tiny $1.5 \%$ ). It then moves the divergent movement of the two economies at the current market rates, although the fact that the EU27 population is significantly larger than the population of the US (roughly by onethird), implying significantly higher per capita income in the US, should also be emphasized. Despite almost constant slower GDP growth, the PPP GDP of the EU27 remains higher than the US until 2010, being almost 5\% lower in 2020. Due to the fluctuations in the dollar exchange rates against the euro (and formerly the mark, the franc, and other EU currencies), the GDP in the exchange rates fluctuates significantly, but in most years America is ahead of the EU27, so the significant weakening of the EU27 started after having reached a high level of 2007 (an 11\% higher GDP than in the US). Specifically, this decline may be linked to a significantly better US response to the Great Recession, namely Washington's more expansive fiscal and monetary policy compared to Brussels', and to the strengthening of the dollar as well. Already in 2015, the EU27 accounts for only three-quarters of the GDP of the US, which is also the case for 2020.

Since 1980, the tendencies of the sizes of the two western economies towards China have been an unprecedented path in the history of civilization, owing to the dramatic economic growth of the world's most populous country. Namely, China's economy had a share of only $2.7 \%(2.3 \%)$ in the world GDP (the GDP PPP) that year, and it increased its share to $3.6 \%$ and $7.4 \%$ twenty years later. Growth continues at a marginally slower pace, even in 2015, when China accounted for $15 \%$ (17\%) of the world GDP. In 2020, its share is estimated at almost $17 \%$ or nearly one-fifth of the global GDP by the PPP. At the same time, the two western economies (the US and the EU27) are recording different trends, with a share in the world GDP at market rates of $25.6 \%$ and $28.7 \%$ in $1980,30.3 \%$ and $21.5 \%$ in $2000,24.4 \%$ and $18.1 \%$ in 2015 and $24.7 \%$ 
and $17.7 \%$ in 2020, respectively (and significantly lower and more declining shares when it speaking about the PPP GDP).

In the long run, the estimates they published in the study China 2049 (Dollar, Huang, \& Yao, 2020, 7-10), the authors suggest that China's economic growth rate is likely to slow to $2.7-4.2 \%$ in 2049 , with its GDP per capita increasing to about two-thirds of the US. In that case, China would overcome the middle-income trap by successfully achieving a high-income status, while becoming by far the largest global economy.

\section{A RELATIVE EU DECLINE}

A conspicuous relative decline of the EU economy began in the late 1990s, and the Great Recession of 2008-09, which lasted much longer in the peripheral EU countries, only revealed the extent of the problem, especially in the EU Member States with a high balance of payments deficits, especially the 'peripheral' EU countries, the so-called PIIGS (Portugal, Italy, Ireland, Greece, and Spain). The relative decline started before 2000, but in the years before 2008, cheap and unreasonable lending concealed the weakness, i.e. the decreasing competitiveness of the European industry.

A decline in the EU's share in the estimated global GDP has been going on for decades and is likely to continue. According to the IMF (2019), the declining dynamics of the European GDP are obvious. Specifically, the EU27's share in the world GDP (calculated at market rates) fell from $21.7 \%$ in 2000 to the estimated $18.6 \%$ in 2020, and the projected $15.8 \%$ a decade later (when China would already account for $21.8 \%$ of the global GDP and the US would account for $20.9 \%$ ). Viewed in terms of the GDP by the PPP, the decline is even more drastic for the EU27: from $21.5 \%$ in 2000 to the estimated $14.2 \%$ in 2020 , and $11.2 \%$ in 2030, while China's share in the same year will be $23.9 \%$, and that of the US $12.4 \%$. The reason for the relative decline of the $\mathrm{EU}$ is the faster average growth of both the US and, especially so, the Chinese economies in the period 1979-2019. Namely, according to the authors' calculations based on the real GDPs of the three economies, the average real growth rate of the US GDP in those four decades was 2.6\%, compared to $1.9 \%$ for the EU, while the growth of China's economy was impressive 9.4\% (and most other developing countries have had a significantly faster economic growth than the EU in recent decades as expected, given the lower starting position).

The relative decline of the EU is also evident through its share in the global FDI, the global industry, and in the world trade as well. For example, the EU share in the world merchandise exports fell from 18.2\% in 2000 to $15.2 \%$ eighteen years later. Even so, the EU (with a share of $15.1 \%$ in the global merchandise imports) is still the largest foreign trade power (ahead of China and the US, accounting for $16.4 \%$ and $10.9 \%$ of the world merchandise exports, respectively, and with a share in the world merchandise imports of $13.8 \%$ and $16.4 \%$, respectively), with the merchandise exports worth EUR 1956 billion and the merchandise imports of EUR 1980 billion (European Parliament, 2019). Solid growth in commodity trade (by $3.5 \%$ in euros) continued in the first eleven months of 2019 (Eurostat, 2019).

Related to the above, investors note that the EU stock market has consistently been weak for two decades, implying a lack of faith in the Union's long-term prospects. D. Moyo (2020), however, believes that there are four key areas where the EU could establish itself as a global player. The first is trade, because even after Brexit, the EU will have a huge market (still the largest in the world) and it is still an extremely desirable trading partner. The second area in which the EU can be a global leader in regulation is Big-Tech, where the EU has in many ways already established itself as a regulatory pioneer. The third area for the vital global role is mediation between the US and China, which are in a trade and technological war, where Brussels could attempt to reconcile even the ideological conflicts of American (neoliberal) capitalism and the Chinese state (capitalist) model. The fourth area is the defense of the so-called Western values, especially individual economic and political freedoms. Related to this is the thinking of J. Fischer (2020), who believes that the EU can no longer afford to lag behind in terms of technology or geopolitical power, especially given its practical responsibility for leading the rest of 
the world with respect to climate change, which will require technological and regulatory innovations.

The Germany-led reduction of the foreign policy to an economic gain (trade) implies that the EU does not have a significant level of relations with individual regional economic powers and China. Looking at the world as a market for ideas, the EU is in a unique position to offer a vision of solving the ongoing problems and the ways to govern the world, without a negative image like the US. The preservation of the cultural identity, the existence of sustainable political forums to solve problematic issues and multinational crime suppression are all the issues in which the EU stands today and which Brussels occasionally manages to make the primary issue of world governance (Igrutinović, 2012, 33).

K. Stoychev (2020) emphasizes the fact that the US and China will always be rivals in the fight for global domination, while the EU (and Russia) will not play such a game and would prefer to rely on soft power, aided by persuasive military power, which will inevitably bring them closer together. Namely, no matter how divided they might be, the EU elites will have no choice but to build a separate military capacity. Obviously, there is the initial phase of building military independence, a decade-long process that will be presented as complementary to NATO (and will remain so until the EU has received its sophisticated weapons and systems under development, including cyberspace). This suggests that, from a geopolitical point of view, the EU might prove to be less prepared to support the US foreign policy actions, something already hinted at during the Second Iraqi War. The occasional lack of foreign or military support for America is mostly the result of the public opinion concerns about the lives of soldiers, rather than the willingness to radically change political relations with the United States. For now, the EU is making efforts trying to change the global governance system by systematically coopting the "revisionist" factors (China, Russia, Iran). The fact that EU countries occasionally sell the hightech technology that has both civilian and military applications complicates the security role of the US in Asia (Nye, 2014).

\section{US DILEMMAS ABOUT THE RISE OF CHINA}

The US is the leader in innovation and technology, has deep financial markets and the world's strongest military, virtually guaranteeing the US global primacy for a foreseeable future. Although China has established itself as a huge economic and political counterweight to the US, largely occupying a critical position in global value chains and, increasingly, as the major source of FDI especially through ambitious transnational infrastructural projects (such as the "Silk Road"), Washington is still able to dominate the global order. However, it is clear that the constant rise of China is a concern for the US, the topic wellknown to international relations theorists. The most prominent of them, such as Alfred McCoy, John Mearsheimer or Barry Buzan, believe that China's strong economic upswing will disrupt the current balance of power, i.e. the US dominance, first in East Asia and then globally. John Mearsheimer believes that, if Chinese growth continues (even with a slight slowdown), the US will face a geopolitical competitor much more serious than the Soviet Union used to be. What he sees as the inevitable outcome is a repeat of the policy of "containment", this time towards China, preferably in cooperation with the successor to the USSR: Russia (Mearsheimer, 2016).

A strong slowdown in productivity is a major problem for the US economy, caused by insufficient innovation and, consequently, corporate investment, workers' inadequate qualifications and the longterm unsustainability of the pension and healthcare systems (due to the rapidly aging population), all of which are the structural problems where it is unlikely to achieve more significant improvements in the short term. The problem is that China has been brought closer to USA and reached the countries of Western Europe, even in highly-sophisticated technologies, e.g. artificial intelligence. In addition, the Chinese are no longer copywriters, but rather those who are slowly taking primacy according to the number of patents.

The trade war, whose truce is likely to last until the November 2020 US elections, also marks the end of the US policy that has lasted since Nixon's "inauguration" back in the early 1970s. The belief that modernization 
would encourage a more liberal China, which would be pro-American, is gone. In Washington, China's economic strategy is considered to be an integral part of the hidden overall approach of China's ruling elite in their "Grand Strategy". The White House believes that, whether through the control of the economy through the "Silk Road" or through state-owned enterprises, China is willing to use the huge capital it has in trying to gain control of a range of strategic assets, such as the global telecommunications network, via its companies (Huawei). Therefore, the proponents of China's isolation in high technology believe that China must be actively prevented from catching up with America's advanced technology. This is compounded by the increasingly pronounced economic and technological separation of "the US and China (decoupling)" as Washington seeks to "pull" China out of global distribution chains. The new Cold War could begin with the division of the global internet (the "splinternet"), i.e. through the technological separation of the two economies, with dangerous military and negative economic consequences (the isolation of the world's leading industrial producer with the largest consumer market would severely disrupt global supply chains).

The US attempt to trade war and, above all, partly block the export of high-tech products and technologies is probably the last serious US strategic action. In this context, R. Boxwell (2020) considers the trade armistice signed in mid-January 2020 only as instantaneous and also considers that Trump has achieved the best "divorce" he could, consequently discovering that the lifestyle with a new bipolar reality will be one of the biggest challenges in the forthcoming decades. Eventual failure, or partial success, would mean that the technological "catchup" of the two largest economies is inevitable and that America's ability to dominate the global order will be dramatically narrowed. Otherwise, the success of the US would imply maintaining the existing world order, where Washington has the dominant role and benefit.

Militarily, through its Indo-Pacific strategy developed in full partnership with Japan and other allies, the US administration is taking action to indicate to Beijing that the cost of any attempt by China to dominate the region will increase. Yet, these moves have not significantly altered Chinese actions in the South China Sea and beyond, nor have they reversed, for the US, the unfavorable changes in the regional balance of power (Edel \& Brands, 2019). This is why many analysts, such as D. Lane (2019), propose a change in the approach and a move towards acknowledging China's rise, and incorporate the country into the hegemonic core, thus accepting the fact that the global economic pole is going to the east and that ignoring Beijing's interests may be too expensive.

\section{CHALLENGES FOR BEIJING}

Since 1978, China has been implementing exportoriented industrialization, liberalizing the private sector, accelerating FDI inflows, and integrating into global trade flows. The real secret lying behind Chinese economic dynamism was "directed improvisation": experimentation at the local level guided by the central government's directives. Investment is undoubtedly the major driver of growth, accounting for as much as $45 \%$ of the GDP in 2018, despite a slowdown since the end of 2013 (Yongding, 2018). With such a share of investment in the GDP, and thus the country's ability to forgo the current spending in favor of savings, every other economy would achieve growth rates similar to China's. Given the particularly strong share of energy investments, based on a large sample of the data covering the period 1953-2012, F. Yuxian, Y. Xiaoling and H. Songke $(2014,98)$ investigate the short- and long-term impact of energy infrastructure investments on China's economic growth. There is a clear long-term equilibrium link between this type of investment and economic growth, with the strongest impact of this type of investment on the GDP growth in the second year, and with this positive impact persisting for full four years. China's economy is recording slow, but favorable structural changes. For example, while the so-called secondary sector of the GDP (predominantly industry, including construction) represented as much as $48 \%$ of China's GDP and the tertiary sector only accounted for $42 \%$ of the GDP in 2006, as early as in $2018,41 \%$ of the 
GDP accounted for the secondary sector and 52\% accounted for services. These are partly related to the increased urbanization of the country, as shown by Y. Wangping and L. Xiaolu (2016, 211), indicating that the quality of urbanization in China has improved since 2004, thus reflecting positively on the economic development of the country.

The continuation of the expansionary fiscal and monetary policy is what can be expected in the years to come, coupled with the difficult job of economic policymakers in the wake of US sanctions in the ongoing trade war. Above all, it will reflect in the continued rapid growth of low-cost lending (largely to state-owned companies), which is faster than economic growth, which will remain a strong instrument of the Beijing Government in achieving high GDP growth. Specifically, extensive loans and fiscal stimuli sustain many factories and construction sites. At the same time, Beijing's attempts to internationalize its currency have but modest effects, in large part because of the possibility of implementing interest rate and exchange rate, or monetary, policies, due to the eventual full convertibility of the Yuan, would significantly limit the proactive (Keynesian) economic policy. It is certain that the full convertibility of the Chinese currency would imply additional efforts to maintain stable economic growth and the Yuan exchange rate, as well as low inflation (Jankovic, 2018, 85).

The new version of the old famous "Made in China $2025^{\prime \prime}$ plan, which was quietly dropped from official announcements amidst stiff opposition from the US (who thought the outlined ambitious goals were largely reliant on the government subsidies and forced technology transfers at the expense of the US companies), was unveiled at the end of November 2019, singling out a group of the companies that will become the "2025 National Sector Champions". This new document provides the evidence that the trade war and the aggressive US policy have done little to change China's intention to dominate new technologies with government support (Wang \& Behsudi, 2019). Specifically, China aims to increase its reliance on the domestic production of the key components, including chips and control systems, to $75 \%$ by 2025 , thus reflecting Beijing's determination to reduce its dependence on imports. By the way, the "Made in China 2025" plan was China's idea to improve its high-tech industry and reduce its dependence on imports, as Washington's increased restrictions on advanced technologies being exported to China made Beijing frustrated by its reliance on foreign suppliers.

Thus, China should be expected to adhere to its strategic patience policy simultaneously implementing the necessary reforms, giving priority to the maintenance of social and political stability. The reality is that the fundamental civilizational tensions between the US and China could continue in the future, and the possible outcome is, among other things, decoupling in the digital world, which would result in a serious lag behind globalization. This very dangerous scenario for Beijing, where China would be partially isolated from the West, would force Beijing to significantly cooperate with its Asian neighbors.

R. Dalio (2018) thinks it is wrong to view China as a communist country; instead of that, what is happening in China is "state capitalism", in which strategically important companies are supported in order for them to become very competitive, with an economy full of entrepreneurship and markets that have a great freedom. Although different, China is governed similarly to Singapore; more from top to bottom, with the primary goal of being competent in decision-making places. He says that, although China is a competitor and although it will be significantly larger than the US soon, it is not at all certain that the capacities of either country will do excessive harm to the other over a very long timeframe.

\section{CONCLUSION}

Based upon the projections of future GDP trends for the US, China, and the EU27 in the period 2025-2030 (based upon the past trends and the IMF projections), our calculations bring us to the year (2029 or 2030) in which China might become the world's largest economy, surpassing the US. This confirms the basic research hypothesis, since changes in the economic size of the major global actors, as a rule, trigger 
geopolitical consequences. An additional contribution reflects in addressing an important topic for our academic public, which, despite its many implications for our country, receives virtually no attention at all, for which reason this paper might encourage domestic authors to further elaborate on the topic in future research. Introducing the EU27 - as a major player in the overall geo-economic equation, albeit less important than the US and China - into the analysis gives the paper additional significance.

The limitation of the presented research study certainly implies its focus on only one indicator (or two indicators), which, although being the most important indicator of the overall size of the economies, is insufficient to consider the overall geoeconomic position of the major global players. In addition, estimating future GDP trends both by the IMF and the authors is always a difficult task to do, which carries a high risk in terms of precision.

What is clear from all this is the fact that Beijing wants a more significant role in creating the inclusive and equitable global order which is in line with its national interests and worldviews and which can only be brought to reality if that country, with the new status, is seen as legitimate in the eyes of other nations. In this context, China's problems are, among other things, subsidizing monopoly state-owned enterprises and a relatively closed market for services. The additional problem is political legitimacy, i.e. the negatively perceived authoritarianism of the regime in the West. Indeed, China does cooperate with the US on global climate change, the Ebola virus, and North Korea's nuclear program, but this is far from sufficient (Economy, 2017).

The violent transitions of power, in which the rising powers (like China today) overthrow the leading power on the throne (the US), thus creating a new order with a large and violent burst, are not inevitable. In fact, there are a significant number of generally accepted and powerful international institutions (the UN, the EU, the WTO) in the world today that have had relatively great success in amortizing crises and regulating relations between countries (Igrutinović, 2012, 35).
While some authors (Brooks \& Wohlforth, 2008) believe that the unipolar world is still viable and that, as such, the same will be dominant in the near future, it seems that there are more convincing theses about the forthcoming multipolarity, i.e. more balanced power centers (Gnessoto \& Grevi, 2006). The bipolar world could emerge as a rerun of the Cold War (China instead of the USSR).

What may probably be expected is a continued trend of the dispersion of authority and power globally, which will be accelerated by the emergence of new global players. The United States will almost certainly remain the leading global power for decades thanks to its ability to push its priorities, its military supremacy and the dominant cultural pattern via strong diplomacy and a network of alliances. While the EU will continue to focus on itself, China's growth will have amplified global implications, fueling the move towards multipolarity or bipolarity. The role of the state may realistically be enhanced, especially in the economy. Unlike in the second half of the previous century, the US has a limited capability of taking unilateral actions, while China benefits greatly from its current geopolitical arrangement and globalization (Nye, 2014).

By all accounts, the "big game" will continue to accelerate throughout the 2020s. Economics will largely determine the new geopolitical constitution. An important, but not crucial, moment will be at the end of this decade, when there is an increasing certainty that China will take the place of the leading global economy.

\section{ACKNOWLEDGEMENT}

This paper was written as part of the 2020 Research Programs of the Institute of European Studies and the Institute of Social Sciences, with the support of the Ministry of Education, Science and Technological Development of the Republic of Serbia. 


\section{REFERENCES}

Boxwell, R. (2020). China and the US were never going to live happily ever after, so Trump brokered the best divorce he could. South China Morning Post, 24 Jan, 2020. Retrieved January 25, 2020, from https://www.scmp.com/comment/ opinion/article/3047177/china-and-us-were-never-goinglive-happily-ever-after-so-trump

Brooks, S., \& Wohlforth, W. (2008). World out of Balance: International Relations and the Challenge of American Primacy. Princeton, New Yersey: Princeton University Press.

Centre for Economics and Business Research - CEBR. (2019). World Economic League Table 2020. London, UK: December 2019, 11th edition.

Dollar, D., Huang, Y., \& Yao, Y. (2020). China 2049: Economic challenges of a rising global power. Brookings Institution Press, Retrieved January 31, 2020, from https://www. brookings.edu/wp-content/uploads/2020/01/FP_20200106_ china_2049_dollar_huang_yao.pdf

Dalio, R. (2018). Chinese-American misunderstandings, disputes, and wars. Bridgewater Associates LP, Retrieved July 2, 2019, from https://www.bridgewater.com/resources/ Chinese-American_Misunderstandings_Disputes_and_ Wars.pdf

Economy, E. (2017). Beijing is no champion of globalization. The nyth of Chinese leadership. Foreign Affairs, Retrieved March 13, 2018, from https://www.foreignaffairs.com/articles/ china/2017-01-22/beijing-no-champion-globalization

Edel, C., \& Brands, H. (2019). The real origins of the US-China Cold War. Foreign Policy, Retrieved February 22, 2020, from https:/foreignpolicy.com/2019/06/02/the-real-origins-ofthe-u-s-china-cold-war-big-think-communism/

European Parliament. (2019). The EU's position in world trade in figures. Retrieved February 2, 2020, from https://www.europarl.europa.eu/news/en/headlines/ economy/20180703STO07132/the-eu-s-position-in-worldtrade-in-figures-infographic

Eurostat. (2019). November 2019 Euro area international trade in goods surplus €20.7 bn. Retrieved February 2, 2020, from https://trade.ec.europa.eu/doclib/docs/2013/december/ tradoc_151969.pdf
Fischer, J. (2020). What Kind of Great Power Can Europe Become? Retrieved February 4, 2020, from https://www.projectsyndicate.org/commentary/european-union-great-powerpotential-by-joschka-fischer-2020-01

Gnessoto, N., \& Grevi, G. (2006). The New Global Puzzle: What World for the EU in 2025? Paris, F: Institute for Security Studies.

Huang, C. (2020). If China thinks it's overtaking the US any time soon, here's a wake-up call. South China Morning Post, Retrieved February 3, 2020, from https://www.scmp.com/ week-asia/opinion/article/3006892/if-china-thinks-itsovertaking-us-any-time-soon-heres-wake-call

Igrutinović, M.(2012). Evropskaspoljna politikanadvostrukom koloseku promena: Uticaj novih institucionalnih rešenja i pitanje aktuelne globalne uloge. Pravo i društvo, br. 1/2012. $27-40$.

IMF. (2019). World Economic Outlook Database. October 2019 (IMF staff estimates)

IMF. (2020). World Economic Outlook Database. January 2020. Retrieved February 1, 2020, from https://www.imf.org/ en/Publications/WEO/Issues/2020/01/20/weo-updatejanuary2020

Jankovic, N. (2018). Perspectives of the International Monetary System. Economic Horizons, 20(1), 73-87. doi:10.5937/ ekonhor1801075J

Jun, Z. (2020). The Coronavirus Will Not Cripple China's Economy. Projects Syndicate, Retrieved February 11, 2020, from https://www.project-syndicate.org/commentary/ china-coronavirus-three-factors-limit-economic-impactby-shang-jin-wei-2020-01

Kennedy, S. (2018). China will overtake the U.S. economy in less than 15 years, says HSBC, challenging Trump's claim. Bloomberg, Retrieved December 24, 2019, from https://www. bloomberg.com/news/articles/2018-09-25/hsbc-sees-chinaeconomy-set-to-pass-u-s-as-number-one-by-2030

Lane, D. (2019). US-China Relations: Trade Wars or Countervailing Powers? Valdai Club, Retrieved Januuary 31, 2020, from http://valdaiclub.com/a/highlights/us-chinarelations-trade-wars-or-countervailing-po

Mearsheimer, J. (2016). Crouching Tiger: John Mearsheimer on Strangling China \& the Inevitability of War. Death By China, Retrieved March 9, 2018, from https://www.youtube. com/watch?v=yXSkY4QKDIA 
Moyo, D. (2020). What Does Europe Have to Offer? Project Syndicate, Retrieved February 9, 2020, from https://www. project-syndicate.org/commentary/european-unionstrengths-for-global-role-by-dambisa-moyo-2020-02

Nye, J. (2014). America's Overrated Decline. Project Syndicate, Retrieved June 16, 2018, from https://www.project-syndicate. org/commentary/declining-public-trust-in-us-institutionsby-joseph-s--nye-2014-10

OECD. (2018). The Long View: Scenarios For the World Economy to 2060. OECD Economic Policy Paper, Paris, July 2018 No. 22. 1-51. doi.org/10.1787/2226583X

PwC. (2017). The World in 2050: The Long View, How will the global economic order change by 2050? PriceWaterhouse Coopers, 1-14.

Stoychev, K. (2020). If You Aren't at the Table, You'll Be on the Menu: Why Europe Seeks a More Independent Role in World Affairs. Valdai Club, Retrieved February 11, 2020, from https:/valdaiclub.com/a/highlights/eu-us-if-you-arenot-on-the-table/

Tang, F. (2019). China revises up 2018 GDP after new census, making it easier to double size of economy in 2020. South China Morning Post, Retrieved December 12, 2019, from https://www.scmp.com/economy/china-economy/ article/3038877/china-revises-2018-gdp-after-new-censusmaking-it-easier
Wang, O., \& Behsudi, A. (2019). China s new industrial policy dismissed as 'Made in China 2025' rehash by critics in Washington. South China Morning Post, Retrieved December 24, 2019, from https://www.scmp.com/economy/chinaeconomy/article/3038590/chinas-new-industrial-policydismissed-made-china-2025-rehash

Wangping, Y., \& Xiaolu, L. (2016). An assessment of China's new urbanization level. Economic Horizons, 18(3), 201-213. doi:10.5937/ekonhor1603201W

Yongding, Y. (2018). Has China's Economic growth finally stabilized? Project Syndicate, Retrieved February 9, 2020, from https://www.project-syndicate.org/commentary/ china-prospects-slower-investment-growth-by-yuyongding-2018-01

Yuxian, F., Xiaoling, Y., \& Songke, H. (2014). Electricity investment and economic growth in China. Economic Horizons, 16(2), 85-100. doi:10.5937/ekonhor1402085Y

\author{
Received on $19^{\text {th }}$ February 2020, \\ after revision, \\ accepted for publication on $17^{\text {th }}$ August 2020. \\ Published online on $19^{\text {th }}$ August 2020.
}

Goran Nikolic is a senior research associate at the Institute of European Studies. He obtained PhD at the Faculty of Business Studies, Megatrend University (Belgrade). Areas of his scientific interest are: International Economics, Monetary Economics, Economic History, and Macroeconomics.

Predrag Petrovic a senior research associate at the Institute of Social Sciences (Center for Economic Research). He received his doctorate from the Faculty of Economics (University of Belgrade). Areas of scientific interest are: International economics, Macroeconomics, Environmental Economics, Applied Econometrics. 


\title{
OČEKIVANE TENDENCIJE BDP-A TRI VODEĆE GLOBALNE EKONOMIJE TOKOM 2020-IH: DA LI JE NA POMOLU REBALANS (GEO)EKONOMSKE MOĆI?
}

\author{
Goran Nikolićs i Predrag Petrović \\ ${ }^{1}$ Institut za evropske studije, Beograd \\ ${ }^{2}$ Institut društvenih nauka, Centar za ekonomska istraživanja, Beograd
}

\begin{abstract}
Međunarodni monetarni fond (International Monetary Fund - IMF) predviđa postepeno usporavanje, inače snažnog, rasta kineske ekonomije u prvoj polovini 2020-ih, te anemičan rast zapadnih ekonomija: SAD i posebno EU27. Imajući u vidu praktičnu (i simboličku) važnost dostizanja statusa ekonomije „,broj jedan“, osnovni cilj rada je procenjivanje tendencija BDP-a (i BDP-a PPP) posmatranih ekonomija tokom naredne decenije. Glavni doprinos i nalaz ovog rada je procena budućih kretanja BDP-a za SAD, Kinu i EU27 u periodu 2025-30, na osnovu prethodnih trendova i projekcija IMF-a za 2020-24. Kineska privreda će postati globalno vodeća 2029-2030. Na osnovu izvršenih kalkulacija dokazana je osnovna istraživačka hipoteza, imajući u vidu da promene u globalnoj ekonomskoj poziciji impliciraju značajne geopolitičke posledice. Naime, dok će SAD, skoro izvesno, tokom 2020-ih ostati vodeća globalna sila, a EU nastaviti da bude fokusirana na sebe, ekonomski rast Kine će imati rastuće globalne konsenkvence, podstičući kretanje ka disperziji autoriteta. Taj zaključak je u skladu sa tvrdnjama većine relevatnih autora, koji potenciraju sve limitiraniju mogućnost SAD za unilateralne akcije.
\end{abstract}

Ključne reči: bruto domaći proizvod, ekonomski rast, Kina, SAD, EU27, globalni poredak

JEL Classification: F2, F50, 047

\section{UVOD}

U akademskim krugovima, sve čěśe se postavlja pitanje kada bi moglo doći do sustizanja SAD od strane Kine, kada je u pitanju ukupni BDP meren tržišnim kursevima, koji se još uvek smatra

* Korespondencija: G. Nikolić, Institut za evropske studije, Trg Nikole Pašića 11, 11000 Beograd, Republika Srbija;

e-mail: gorandrnikolic@gmail.com najvažnijim pokazateljom ukupne veličine ekonomije. Po projekcijama Međunarodnog monetarnog fonda (International Monetary Fund - IMF, 2019), privreda Kine će, u periodu 2020-24, blago usporavati, te će poslednje godine tog razbodlja njen rast iznositi 5,5\%. Istovremeno, rast EU27, te $\mathrm{SAD}$ će biti znatno niži (1,5\%, odnosno $1,6 \%$, u 2024, posle usporavanja tokom posmatranog perioda). Posledično, ove tendencije vode ka daljem smanjivanju razlika između BDP-ova posmatranih privreda. 
Predmet istraživanja $\mathrm{u}$ ovom radu su tri najveće svetske ekonomije: Sjedinjene Američke Države (SAD), Evropska unija (EU27) i Kina (čije su veličine izražene kroz BDP ili BDP PPP), odnosno, efekti promena relativnih težina tih ekonomija na buduću globalnu geopolitičku konstelaciju. Ovo ima važne konsekvence, budući da je status najveće svetske privrede, po pravilu, sa određenim vremenskim zaostatkom, dovodio do vodeće uloge te iste zemlje globalno. Naime, indikativni su primeri snažnog ekonomskog uspona Britanije tokom 15 i 16. veka, te SAD od sredine 19. veka, posle čega je usledila globalna dominacija (vojna, diplomatska, kulturološka, ekonomska) te dve države.

Osnovni cilj rada je da se, na osnovu dostupnih podataka o dosadašnjem kretanju, projekcijama IMF-a, te kalkulacijama autora za BDP-a za tri vodeće svetske ekonomije do 2030, procene visine BDP-a i BDP-a PPP (Purchasing Power Parity - paritet kupovne moći) tih ekonomija - radi eventualnog utvrđivanja godine kada bi privreda Kine mogla postati najveća na svetu. Dakle, cilj ovog rada je da se, procenjivanjem dinamike BDP-ova najvećih svetskih ekonomija, te oslanjanjem na teorijske pretpostavke vezane za geopolitički uspon i eventualnu svetsku dominaciju zemalja sa najvećim globalnim BDP, ukaže na veliki, transformativan, značaj trenutnog i očekivanog (izrazito nejednakog) ekonomskog rasta tih privreda.

Shodno definisanom predmetu i postavljenom cilju istraživanja, u radu će biti testirana sledeća hipoteza:

$\mathrm{H}:$ Ekonomija Kine, mereno tržišnim kursevima, krajem treće decenije XXI-og veka će prestići ekonomiju SAD i postati najveća globalna ekonomija.

Konkretan kvantitativni metodološki pristup, koji će biti primenjen u testiranju postavljene hipoteze, izložen je $u$ trećem delu rada. Inače, u radu se primenjuje kvalitativna i kvantitativna metodologija. Primena kvalitativne metodologije ogleda se $u$ referisanju na srodne, uglavnom inostrane, studije (koje su bazirane na teorijskim uopštavanjima i iskustvima naučnika koji su se bavili istim ili sličnom problemom) u cilju kreiranja teorijske podrške za primenu kvantitativne metodologije. Koriste se metod analize i sinteze, indukcija i deduciju, te posebno metod komparacije. Akcenat je na kvantitativnoj metodologiji, odnosno, na projektovanju kretanja BDP-a tri posmatrane ekonomije, gde su svi podaci preuzeti iz baze IMF-a (2019).

$\mathrm{U}$ drugom delu rada biće predstavljene studije koje se bave praktično istom temom, ali koje, faktički, zanemaruju analizu EU27, za koju smatramo da je, kao deo Zapada, važan element ukupne (geo)ekonomske jednačine. Potom, ukazuje se na primenjenu metodologiju, a u naredna tri dela razmatraju se osnovne privredne performanse i dugoročne (geo) ekonomske perspektive tri najveće svetske ekonomije: SAD, EU27 i Kine. Sledi zaključak u kome se ukazuje na mogući scenario, inače rizičnog balansiranja vodeće i rastuće sile (praktičnog izazivača), koje je, kroz istoriju, često vodilo ka vojnim konfrontacijama, sve ovo imajući u vidu krucijalan značaj ekonomske snage za projektovanje geopolitičke moći.

\section{PREGLED LITERATURE}

Sa snažnim privrednim rastom Kine, koji traje već četiri decenije, pojavljuje se svi više studija u kojima se pokazuje da će ta ekonomija u dogledno vreme postati najveća na svetu. Prema prognozi koju su dali ekonomisti kompanije HSBC Holdings Plc, u studiji koja je obuhvatila 75 najvećih svetskih ekonomija, Kina će postati vodeća globalna ekonomija do 2030, sa BDP-om koji će iznositi 26 hiljada milijardi dolara. Kinezi će, takođe, nastaviti da daju najveći doprinos globalnom rastu i tokom 2020-ih (Kennedy, 2018).

Organizacija za ekonomsku saradnju i razvoj (OECD, 2018, 8) projektuje nastavak usporavanja rasta realnog BDP-a globalno, ali će rast zemalja u razvoju i pored toga ostati znatno brži od onog kod industrijalizovanih zemalja. Kao posledica, udeo proizvodnje OECD-a u svetskoj proizvodnji, koji je već pao sa 72\% u 2000. na nešto ispod 54\% 2019, (po paritetu kupovne moći), će se smanjiti na $43 \%$ do 2060. Kineski udeo u svetskoj proizvodnji dostići će vrhunac tokom 2030-ih, sa oko 27\%, dok će učešće Indije nastaviti da raste, sa obe zemlje znatno iznad udela SAD-a. 
U studiji PriceWaterhouse Coopers (PwC, 2019, 1920), prognozira se da će ekonomija Kine postati veća od ekonomije SAD pre 2030, zahvaljujući, pre svega, smanjivanju jaza u produktivnosti između dve zemlje, a imajući u vidu da je kineska populacija četiri puta veća. Po paritetu kupovne moći, Kina je već od 2014. najveća ekonomija na svetu (slede SAD, EU27 i Indija). Snažan rast Kine i Indije još više smanjuje udeo u svetskom BDP-u koji ima EU27 i predviđa se da će udeo ovog ekonomskog entiteta u globalnoj ekonomiji (izraženo u PPP) konstatno padati, na skromnih 9\% u 2050 .

Projekcije Centra za ekonomska i poslovna istraživanja (CEBR, 2019, 75) ukazuju da bi Kina mogla postati najveća svetska ekonomija nešto kasnije, 2033, pretekavši SAD sa privrednim rastom koji je baziran na savremenim tehnologijama. Ova procena je bazirana na relativno umerenim stopama rasta za koje se očekuje da će iznositi u proseku 5,4\% 2019-24, 5,2\% 2024-29. i 4,3\% 2029-34.

C. Huang (2020), pak, potencira da se percepcija da je Kina globalna sila broj 2 i na putu da postane broj 1 temelji na dve upitne pretpostavke - da će se snažan rast Kine nastaviti, i da se BDP može izjednačavati sa snagom države. Ovaj autor ukazuje da se rast kontinuirano usporava od vrhunca 2007, da postoje sumnje u pogledu tačnosti podataka, kao i da postoje upozorenja da bi se privredni rast mogao stabilizovati na nivou američkog, u kom slučaju Kina nikada ne bi sustigla SAD. Naime, rast BDP-a je usko povezan sa mehurima na tržištu nekretnina, špekulacijama i kapitalnim investicijama koje vodi država, što je rezultiralo suvišnim kapacitetima i porastom teško naplativih zajmova. Čak i ako, po vrednosti BDP-a, Kina nadmaši SAD, ne sledi da će Kina biti ekonomski moćna i bogata kao SAD, jer BDP ne znači nužno poboljšanja u blagostanju pojedinaca, već je za to potrebno korisiti isti pokazatelj ali u per capita izrazu. U skladu sa podacima IMF (2019), BDP per capita Kine u 2019, sa 10,2 hiljade američkih dolara, je oko šest puta manji od BDP-a per capita SAD, što je, pre svega, uzrokovano većom produktivnošću rada u SAD.

\section{METODOLOGIJA}

Primenjena metodologija uzima kao referentne procene IMF (2019) o visini BDP datih ekonomija, čije su procenjene vrednosti (izražene u tekućim dolarima), date zaključno sa 2024. Polazi se od bazične pretpostavke (broj jedan) da će se nominalni rast BDP-a, ostvaren u 2024, zadržati tokom narednih pet, odnosno, šest godina (posebno važno, nominalni rast BDP-a za Kinu u toj godini je niži nego prosek za period 2020-24). Imajući u vidu da nominalni rast BDP inkorporira pored realnog rasta BDP-a, BDP deflator, te eventualne kursne promene, ovaj pristup bi, eventualno, mogao da bude metodološki prihvatljiv. Međutim, imajući u vidu da ekonomija koja brže raste, generalno, ima tendenciju da u apsolutnom izrazu ima veće varijacije nominalnog i realnog BDP-a, primenjen je alternativni pristup (pretpostavka broj dva), čime je nominalna stopa rasta Kine značajno oboriena (za po prosečnih $0,7 \%$ ), u periodu posle 2024 , dok su podci za SAD i EU27 ostavli nepromenjeni. Potom je primenjen konzervativniji pristup (pretpostavka broj tri), gde je fazno smanjivan rast nominalnog (i faktički realnog) BDP-a Kine nakon 2024, za po dodatnih 0,2\%, zaključno sa 2030, (kada je realni rast BDP Kine procenjen na relativno skromnih 4,3\%). Kada je u pitanju EU27, odnosno, EU bez Velike Britanije, podaci za BDP su izračunati oduzimanjem BDP te zemlje od podataka za EU28, da bi potom bio primenjen raniji princip (da će nominalni rast iz poslednje projektovane godine za EU od strane MMF-a biti zadržan), što se može smatrati optimističnom pretpostavkom za EU.

$\mathrm{Na}$ osnovu navednih projekcija MMF-a i dodatnih kalkulacija autora za posmatrane ekonomije, uključujući i svetsku, da bi se dobila učešća (posmatrano po tekućim tržišnim kursevima i po PPP), dobijeni su rezultati koji su u skladu sa većim delom prethodno citirane literature. Naime, polazeći od pretpostavke broj jedan (konstantan nominalni rast kineskog BDP od 8,1\% nakon 2024.), pretpostavke broj dva (konstantan nominalni rast BDP Kine od $7,4 \%$ nakon 2024), i pretpostavke broj tri (konstantno umanjenje nominalnog rasta BDP-a Kine za 0,2\%, $0,4 \%, 0,6 \%, 0,8 \%, 1 \%$ i za 1,2\% 2025-2030, bivajući relativno skromnih 6,9\% u poslednjoj observiranoj godini), onda bi u 2029, (pod pretpostavkom broj 
jedan), odnosno, u 2030, (pod pretpostavkom broj dva i tri), BDP Kine prestigao BDP Kine, dok bi se kada je u pitanju EU27 to desilo već 2022 (Slika 1). Dakle, i sa dosta konzervatnim pretpostavkama (broj dva i tri), rezultat je marginalno drugačiji: pomeranje godine sustizanja na 2030, što ukazuje da se trend snažnog rasta kineske ekonomije, i njen uspon na svetski pijadestal, teško može zaustaviti.

Po paritetu kupovne moći, BDP Kine će 2030. biti približno jednak zbirnom BDP-u za ove zapadne ekonomije (93\% veći od BDP-a SAD i za 113\% od BDP-a EU27), pod bazičnom pretpostavkom broj jedan (Slika 2).

Ovde treba dodati da kineski podaci o BDP izgledaju nešto bolje posle modifikacija $\mathrm{u}$ četvrtom kineskom ekonomskom popisu. Naime, novembra 2019. Kina je revidirala svoj BDP za 2018. na osnovu rezultata novog nacionalnog popisa stanovništva, te je BDP za 2018. povećan za 2,1\%, budući da se smatra da je veličina ekonomije potcenjena u uslužnom sektoru, zbog nedavnog brzog prelaska na digitalni i uslužni sektor (Tang, 2019). Ova revizija nije uneta u projekcije u ovom radu, i mogla bi biti značajno veća od očekivanog pada BDP-a usled Corona virusa. Naime, očekuje se da bi najavljena ekspanzivnija fiskalna i monetarna politika trebalo da utiče da se posle značajnog smanjenja rasta BDP-a u prvom tromesečju 2020, (za polovinu ili trećinu), godišnje (anualizovano) smanjenje rasta BDP ograniči na 0,5-1\%, što bi značilo još uvek visok rast od 5\% do 5,5\% u 2020. (Jun, 2020). Dodatno, postoje minimalne promene $\mathrm{u}$ januarskom izveštaju MMF (2020) gledajući procenjene stope rasta BDP-a SAD-a i Evrozone (smanjenje za po $0,1 \%$ za 2020) i Kinu (povećanje za 0,2\% u 2020, te pad od 0,1\% u 2021).

Interesantno je za prvu godinu, za koji imamo uporedivo podatke (1980), po paritetu kupovne moći, ekonomija EU27 je čak za trećinu veća od ekonomije SAD, (tačnije za 34,2\%), dok su iste godine BDPovi po tržišnim kursevima približno jednaki (EU ima BDP manji za neznatnih 1,5\%). Potom, počinje divergentno kretanje dve ekonomije po tekućim tržišnim kursevima, iako ne treba smetnuti s uma da je populacija EU27 znatno veća od populacije SAD (grubo za trećinu), što implicira značajno viši dohodak per capita u SAD. BDP PPP EU27 uprkos skoro konstantnom sporijem rastu zadržava višu vrednost od američkog sve do 2010, da bi 2020. bio niži

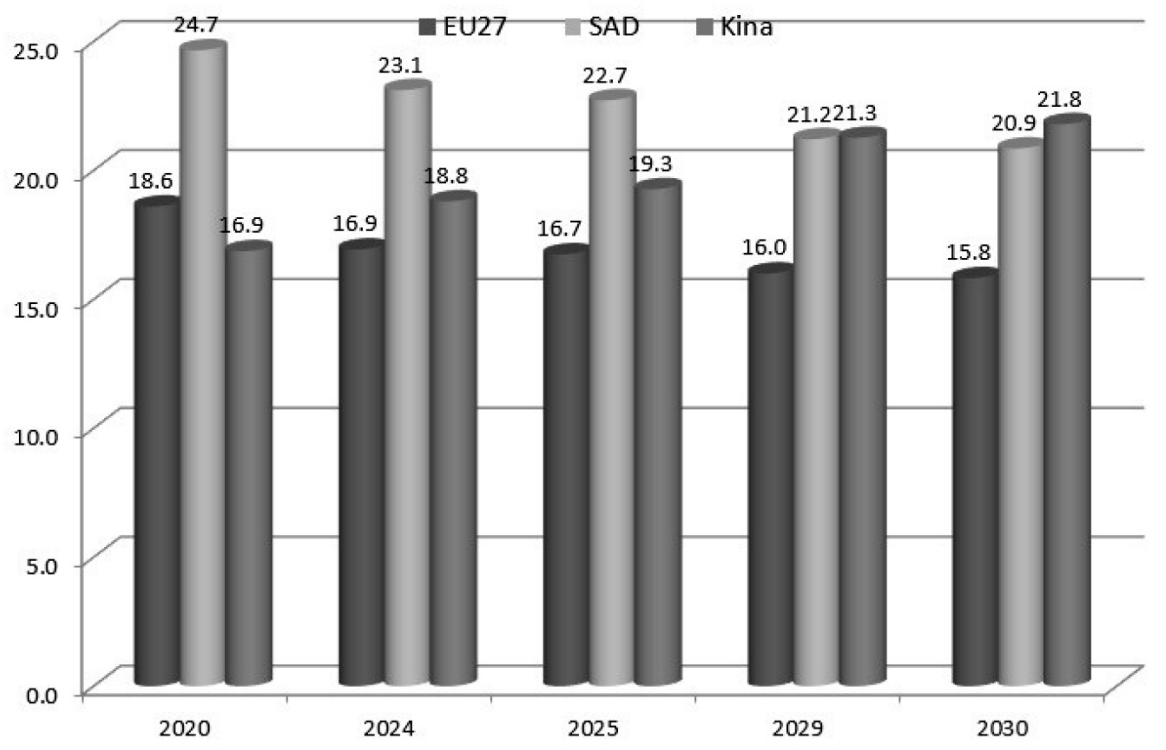

Slika 1 Udeo vodećih ekonomija u svetskom BDP-u 


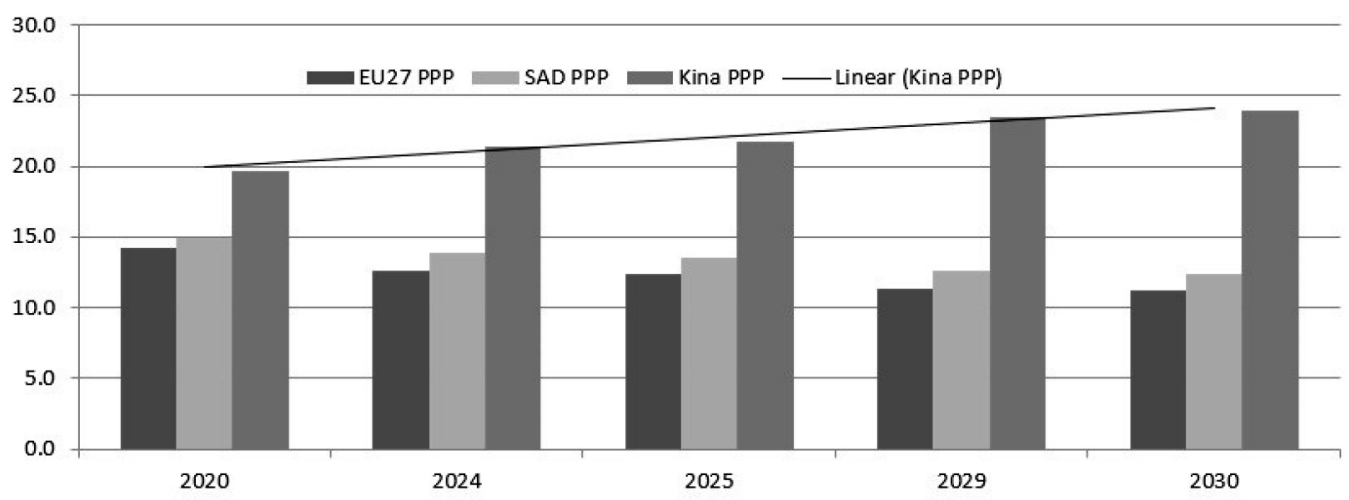

Slika 2 Udeo BDP po kupovnoj moći (PPP) vodećih ekonomija u svetskom BDP-u

Izvor: Autori, na osnovu IMF, 2019.

za skoro 5\%. Zbog oscilacija kurseva dolara prema evru (i ranije marki, franku, i drugim valutama EU) BDP u tržišnim kursevima znatno više varira, ali u većini godina Amerika je ispred EU27, da bi značajno slabljenje EU27 počelo posle dostignutog visokog nivoa 2007, (za 11\% viši BDP od američkog). Naime, taj pad se može povezati sa znatno boljim odgovorom SAD na Veliku recesiju, odnosno, espanzivnijom fiskalnom i monetarnom politikom Vašingtona $u$ odnosno na Brisel, kao i jačanjem dolara. Već 2015, EU27 čini tek tri četvrtine BDP-a SAD, što je slučaj i 2020.

Odnosi dve zapadne ekonomije prema kineskoj, od 1980, prolaze kroz, $\mathrm{u}$ istoriji civilizacije, neviđen put $\mathrm{i}$ to dominatno zahvaljujući dinamičnom ekonomskom rastu najmogoljudnije zemlje sveta. Naime, ekonomija Kine te godine ima udeo od tek 2,7\% u svetskom BDP-u (BDP PPP), da bi već dvadeset godina kasnije povećala svoje učešće na 3,6\%, odnosno, 7,4\%. Rast se nastavlja marginalno smanjenom dinamikom i Kina, 2015, čini 15\% svetskog BDP-a, a 2020, procenjenih skoro $17 \%$, odnosno, gotovo petinu globalnog BDP po kupovnoj moći. Istovremeno, dve zapadne ekonomije, SAD i EU27, beleže drugačije trendove, imajući učešće u svetskom BDP po tržišnim kursevima od 25,6\% i $28,7 \%$ u $1980,30,3 \%$ i $21.5 \%$ u $2000,24.4 \%$ i $18,1 \%$ u 2015. i 24,7\%, odnosno 17,7\% u 2020, (i znatno niže i opadajuće udele kada je u pitanju BDP PPP).
$\mathrm{U}$ dugoročnim procennama iznetim u studiji Kina 2049 (Dollar, Huang \& Yao, 2020, 7-10), autori polaze od toga da će se stopa kineskog ekonomskog rasta, verovatno, usporiti na 2,7-4,2\% u 2049, pri čemu će se njen BDP per capita povećati na oko dve BDP per capita SAD. U tom slučaju, Kina bi prevazišla middle income trap, sa uspešnim dostizanjem statusa zemlje sa visokim dohotkom, istovremeno, postajući ubedljivo najveća globalna ekonomija.

\section{RELATIVNI PAD EU}

Izraženi relativni pad ekonomije EU traje od kraja 1990-ih, a Velika recesija 2008-09, koja je u perifernim zemljama EU trajala znatno duže, samo je razotkrila razmere problema, posebno u članicama EU sa visokim deficitima platnog bilansa, gde prednjače periferne zemlje EU, takozvane PIIGS (Portugal, Italija, Irska, Grčka, Španija). Relativni pad je počeo i pre 2000, ali je u godinama pre 2008, jeftino i nerazborito kreditiranje prikrivalo slabost, odnosno, smanjenu kompetitivnost, evropske industrije.

Pad udela BDP-a EU27 u procenjenom svetskom BDP-u traje decenijama i po svemu sudeći će se nastaviti. Prema podacima IMF (2019), vidljiva je opadajuća dinamika evropskog BDP-a. Naime, udeo EU27 u svetskom BDP-u (računato po tržišnim kursevima) pao je sa $21,7 \%$ 2000, na procenjenih $18,6 \%$ 2020, i projektovanih 15,8\% deceniju kasnije (kada će 
Kina već činiti 21,8\% globalnog BDP-a, a SAD 20,9\%). Posmatrano po BDP PPP, pad je još drastičniji za EU27: sa $21,5 \% 2000$, na procenjenih $14,2 \%$ 2020, i $11,2 \%$ 2030, dok će iste godine udeo Kine iznositi 23,9\% a SAD 12,4\%. Razlog relativnog opadanja EU27 je brži prosečni rast ekonomije SAD i, posebno, ekonomije Kine u periodu 1979-2019. Naime, prema obračunu autora, na osnovu realnih BDP-ova tri ekonomije, prosečna realna stopa rasta BDP SAD-a u te četiri decenije iznosila je 2,6\%, naspram 1,9\% za EU27, dok je višestruko snažniji bio rast ekonomije Kine, koja je tokom poslednje četiri decenije rasla po stopi od 9,4\% (i većina ostalih zemalja u razvoju imala je znatno brži ekonomski rast od EU27 poslednjih decenija, što je i očekivano, imajući u vidu nižu startnu poziciju).

Relativno opadanje EU27 vidljivo je i na primeru udela u globalnim stranim direktnim investicijama (SDI), industrijskoj prozvodnji u globalnoj industriji, ali i u učešću u svetskoj trgovini. Na primer, udeo EU27 u svetskom robnom izvozu pao je sa $18,2 \%$ 2000, na $15.2 \%$ osamnaest godina kasnije. I pored toga, EU27 je (sa udelom od 15,1\% u globalnom robnom uvozu) još uvek najveća svetska spoljnotrgovinska sila (ispred Kine i SAD, čiji je udeo u svetskom robnom izvozu $16,4 \%$, odnosno, $10,9 \%$, a u robnom uvozu $13.8 \%$, odnosno, 16,4\%), i to sa robnim izvozom vrednim 1956 i robnim uvozom od 1980 milijardi evra (European Parliament, 2019). Solidan rast robne trgovine (za 3,5\% izraženo u evrima) nastavljen je i u prvih jedanaest meseci 2019 (Eurostat, 2019).

Povezano sa napred navedenim, investitori primećuju da je tržište akcija u EU27 već dve decenije konstantno slabo, što implicira nedostatak vere $\mathrm{u}$ dugoročne izglede unije. D. Moyo (2020) smatra da postoje četiri ključna područja u kojima bi se EU27 mogla etablirati kao globalni igrač. Prva je trgovina, jer će, i posle Bregzita, EU27 imati ogromno tržište (još uvek najveće na svetu) i biti izuzetno poželjan trgovinski partner. Druga oblast u kojoj EU može biti globalni lider je regulacija, posebno Big-Tech, gde je već na mnoge načine EU postavila sebe kao regulatornog pionira. Treće područje za vitalnu globalnu ulogu je posredništvo između SAD-a i Kine, koje su u trgovinskom i tehnološkom ratu, gde bi Brisel mogao da pokuša da izmiri čak i ideološke sukobe američkog (neoliberalnog) kapitalizma i kineskog državnog (kapitalističkog) modela. Četvrto područje je odbrana $\mathrm{tzv}$, zapadnih vrednosti, posebno pojedinačnih ekonomskih i političkih sloboda. Povezano sa ovim je razmišljanje J. Fischer-a (2020), koji smatra da EU27 ne može više da dozvoli zaostajanje po pitanju tehnologije ili geopolitičke moći, posebno imajući u vidu njenu praktičnu odgovornost da vodi ostatak sveta po pitanju klimatskih promena, za šta će biti potrebne tehnološke i regulatorne inovacije.

Redukovanje spoljne politike na ekonomsku dobit (trgovinu), gde prednjači Nemačka, implicira da EU27 nema značajan nivo odnosa sa pojedinim regionalnim ekonomskim silama i Kinom. Posmatrajući svet kao tržište ideja, EU27 je u jedinstvenoj poziciji da ponudi viziju rešavanja tekućih problema i načina upravljanja svetom, bez negativnog imidža poput SAD. Očuvanje kulturnog identiteta, postojanje održivih političkih foruma za rešenje problematičnih pitanja, suzbijanje multinacionalnog kriminala - sve su to pitanja $\mathrm{u}$ kojima EU27 danas prednjači, i koja Brisel povremeno uspeva da postavi kao primarna pitanja svetskog upravljanja (Igrutinović, 2012, 33).

K. Stoychev (2020) potencira da će SAD i Kina uvek biti suparnici u borbi za globalnu dominaciju, dok EU27 (i Rusija) neće igrati takvu igru i radije će se osloniti na meku snagu, potpomognutu ubedljivom vojnom snagom, što će ih neizbežno zbližiti. Naime, elite iz EU27, bez obzira na to koliko su podeljene, neće imati drugog izbora nego da izgrade zasebni vojni kapacitet. Očigledno je da postoji početna faza izgradnje vojne nezavisnosti; proces koji će trajati deceniju i koji ce biti predstavljen kao komplementaran sa NATO (tako će ostati sve do trenutka kada EU27 dobije svoje sofisticirano naoružanje i sisteme koji su u fazi razvoja, uključujući i sajber-prostor). Ovo navodi da bi se, sa geopolitičkog gledišta, EU27 mogla pokazati manje spremnom da podržava spoljnopolitičke akcije SAD, za šta su postajali nagoveštaji već tokom Drugog iračkog rata. Ipak, povremeni izostanak spoljnopolitičke ili vojne podrške Americi najviše je posledica brige javnog mnjenja za živote vojnika, a ne spremnosti za radikalnu promenu političkih odnosa sa SAD. Za sada, EU27 nastoji da pokušaje promene globalnog sistema upravljanja svede na sistematično 
kooptiranje „revizionističkih“ činilaca (Kina, Rusija, Iran). To što zemlje EU27 povremeno prodaju visoku tehnologiju koja ima i civilnu i vojnu primenu, izvesno komplikuje bezbednosnu ulogu SAD u Aziji (Nye, 2014).

\section{DILEME SAD-A POVODOM USPONA KINE}

SAD su vodeće $u$ inovacijama i tehnologiji, imaju duboka finansijska tržišta, te poseduju najjaču vojsku na svetu, što praktično garantuje američki globalni primat u doglednoj budućnosti. Iako se Kina etablirala kao ogromna ekonomska i politička protivteža SAD-u, velikim delom zauzimajući kritičnu poziciju u globalnim lancima vrednosti i, sve više, kao glavni izvor SDI, posebno kroz ambiciozne transnacionalne infrastrukturne projekte (poput Inicijative Pojasa svile), Vašington je još uvek u stanju da dominantno utiče na globalni poredak. Međutim, jasno je da konstatan uspon Pekinga zabrinjava SAD i to je tema kojom se bave poznati teoretičari međunarodnih odnosa. Najugledniji među njima, poput A. Mekoja, Dž. Miršajmera ili B. Buzana, smatraju da će snažan privredni uspon Kine poremetiti trenutni balans snaga, odnosno, dominaciju SAD, prvo u Istočnoj Aziji, a potom i globalno. J. Mearsheimer (2016) smatra da ako se kineski rast nastavi (čak i laganim usporavanjem), SAD će se suočiti sa geopolitičkim takmacem, mnogo ozbiljnijim nego što je to bio Sovjetski Savez. Ono što on vidi kao neizbežan ishod je ponovljanje politike zaprečavanja (contaiment), ovoga puta prema Kini, i to po mogućstvu u saradnji sa Rusijom.

Snažno usporavanje produktivnosti je glavni problem ekonomije SAD-a, čiji uzroci su nedovoljne inovacije i, posledično, investicije korporacija, neadekvatne kvalifikacije radnika, te dugoročna neodrživost penzionog i sistema zdravstvene zaštite (usled naglog starenja populacije), što su sve strukturni problemi, gde je malo verovatno napraviti bitnija poboljšanja kratkoročno. Problem predstavlja to što se Kina čak i u visoko sofistiranim tehnologijama, na primer, veštačkoj intelegenciji, približila SAD i prestigla zemlje Zapadne Evrope. Dodatno, Kinezi više nisu oni koji kopiraju, oni su oni koji polako uzimaju primat po broju patenata.

Trgovinski rat, čije primirje će, verovatno, trajati do novembarskih izbora, 2020, u SAD, znači i kraj politike SAD-a, koja je trajala od Niksonovog "otvaranja" početkom 1970-ih. Uverenje da će modernizacija podstaknuti liberalniju Kinu, koja bi bila proAmerička, je nestalo. U Vašingtonu se smatra da je kineska ekonomska strategija sastavni deo skrivenog celokupnog pristupa kineske vladajuće elite u njenoj 'velikoj strategiji'. Bela kuća smatra da, bilo da se radi o kontroli ekonomije kroz inicijativu 'Pojas Svile', ili kroz preduzeća u državnom vlasništvu, Kina je voljna da koristi ogroman kapital kojim raspolaže $u$ pokušaju da stekne kontrolu nad nizom strateških sredstava, poput globalne telekomunikacione mreže preko svojih kompanija (Huawei). Stoga, zagovornici izolacije Kine na planu visokih tehnologija veruju da Kina mora biti aktivno sprečena da sustigne američku naprednu tehnologiju. S tim je povezano sve izraženije ekonomsko-tehonološko odvajanje SAD i Kine (decoupling), jer Vašington, praktično, nastoji da 'izvuče' Kinu iz globalnih lanaca distribucije. Novi Hladni rat bi mogao da počne sa podelom globalnog interneta (splinternet), odnosno, kroz tehnološko odvajanje dve ekonomije sa opasnim vojnim i negativnim ekonomskim posledicama (izolacija vodećeg svetskog industrijskog proizvođača sa najvećim potrošačkim tržištem bi ozbiljno poremetila globalne lance snadbevanja). Pokušaj SAD da trgovinskim ratom i, pre svega, delimično blokadom izvoza high-tech (visoko tehnoloških) proizvoda i tehnologija je verovatno poslednja ozbilina strategijska akcija SAD. U tom kontekstu, R. Boxwell (2020) smatra da je trgovinsko primirje, potpisano sredinom janaura 2020, samo trenutno i da je Trump postigao najbolji 'razvod' koji je mogao, te će, posledično, otkrivanje načina života s novom bipolarnom stvarnošću biti jedan od najvećih izazova u narednim decenijama. Eventualni neuspeh, ili delimični uspeh, značio bi da je tehnološki catch-up dve najveće ekonomije neizbežan, i da će mogućnost Amerike da dominantno oblikuje globalni poredak biti dramatično sužena. U suprotnom, uspeh SAD bi implicirao održavanjem postojećeg svetskog poretka, gde Vašington ima dominantnu ulogu i korist. 
Militarno posmatrano, administracija SAD, kroz svoju indo-pacifičku strategiju razvijenu u punom partnerstvu s Japanom i drugim saveznicima, preduzima mere koje ukazuju Pekingu da će se povećati troškovi svakog pokušaja Kine da dominira regionom. Ipak, ovi potezi nisu značajno promenili kineske akcije u Južnokineskom moru i dalje, niti su preokrenuli, za SAD nepovoljne promene, $u$ regionalnoj ravnoteži moći (Edel \& Brands, 2019). To je razlog zašto mnogi analitičari, poput D. Lane-a (2019), predlažu promenu pristupa i kretanje ka priznavanju uspona Kine i uključivanje zemlje u hegemonijsko jezgro, na taj način prihvatajući činjenicu da globalni ekonomski pol pomerio ka istoku i da se ignorisanje interesa Pekinga može pokazati kao preskupo.

\section{IZAZOVI ZA PEKING}

Od 1978, Kina je sprovela izvozno orijentisanu industrijalizaciju, liberalizovala privatni sektor, pospešivala priliv SDI i integrisala se u globalne trgovinske tokove. Prava tajna iza kineskog ekonomskog dinamizma bila je „usmerena improvizacija": eksperimentisanje na lokalnom nivou vođeno direktivama centralne vlade. Investicije $\mathrm{su}$, neosporno, glavni pokretač rasta, čineći čak 45\% BDP 2018, i pored usporavanja od kraja 2013 (Yongding, 2018). Sa takvom udelom investicija u BDP-u i, samim tim, sposobnošću zemlje da se odrekne trenutne potrošnje u korist štednje, svaka druga ekonomija bi ostvarivale stope rasta slične kineskim. Imajući u vidu posebno snažan udeo investicija $\mathrm{u}$ energetiku, F. Yuxian, Y. Xiaoling \& H. Songke (2014, 98), na osnovu velikog uzorka podataka, obuhvatajući period 1953-2012, istraživali su kratkoročni i dugoročni uticaj investicija u energetsku infrastrukturu na kineski ekonomski rast. Jasna je dugoročno stabilna ravnotežna veza između ove vrste investicija i ekonomskog rasta, s tim da je uticaj ovog oblika investicija na rast BDP-a najjači u drugoj godini, a taj pozitivni uticaj se zadržava pune četiri godine. Kineska privreda beleži, istina sporo, povoljne strukturne promene. Na primer, dok je 2006, takozvani sekundarni sektor BDP (pretežno industrija, uključujući i građevinu) predstavljao čak
48\% kineskog BDP-a, a tercijarni svega 42\% BDP-a, već 2018, 41\% BDP-a čini sekundarni sektor a 52\% usluge. Ove je izvesno povezano sa pojačanom urbanizacijom zemlje, što pokazuju Y. Wangping and L. Xiaolu (2016, 211), ukazujući da se kvalitet urbanizacije $u$ Kini poboljšao od 2004, pozitivno se odražavajući na ekonomski razvoj zemlje.

Ono što se može očekivati u narednim godinama, povezano i sa otežanim poslom kreatora ekonomske politike usled američkih sankcija u tekućem trgovinskom ratu, je nastavak ekspanzivne fiskalne i monetarne politike. Ona će se, pre svega, ogledati kroz nastavak rapidnog rasta jeftinog kreditiranja (dobrim delom prema državnim kompanijama), koji je brži od ekonomskog rasta, koji će ostati snažan instrument vlade $\mathrm{u}$ Pekingu $\mathrm{u}$ postizanju visokog rasta BDP-a. Naime, obimni krediti i fiskalni stimulansi održavaju mnoge fabrike i gradilišta. Istovremeno, pokušaji Pekinga da internacionalizuje svoju valutu daju skromne efekte, dobrim delom zbog toga što bi mogućnost vođenja kamatne i kursne, odnosno, monetarne politike, zbog eventualne pune konvertibilnosti juana, znatno limitirale proaktivnu, kenzijansku, ekonomsku politiku. Izvesno je da puna konvertibilnost kineske monete podrazumeva dalje napore na održavanje stabilnog ekonomskog rasta i kursa juana kao i niske inflacije (Janković, 2018, 85).

Nova verzija starog plana Made in China 2025, koji je tiho odbačen iz zvaničnih saopštenja usled oštrog protivljenja SAD (koje su smatrale da se izneti ambiciozni ciljevi, uglavnom, oslanjaju na državne subvencije i prinudne transfere tehnologije na štetu kompanija iz SAD), je predstavljena krajem novembra 2019, i tim planom se izdvaja grupa kompanija koje će postati „nacionalni sektorski šampioni 2025”. Ovaj novi dokument pruža dokaze da su trgovinski rat i agresivna politika SAD učinili malo da promene nameru Kine da dominira novim tehnologijama uz državnu podršku (Wang \& Behsudi, 2019). Naime, Kina ima za cilj da poveća svoj oslonac na domaću proizvodnju ključnih komponenti, uključujući čipove i kontrolne sisteme, na $75 \%$ do 2025 , što odražava odlučnost Pekinga da smanji svoju zavisnost od uvoza. Inače, u okviru plana Made in China 2025 bila je ideja Kine da unapredi svoju visoko-tehnološku 
industriju i smanji zavisnost od uvoza, budući da su povećana ograničenja Vašingtona u vezi sa naprednim tehnologijama, koje se izvoze u Kinu, učinila Peking nezadovoljnim zbog oslanjanja na strane dobavljače.

Dakle, treba očekivati da će se Kina pridržavati svoje politike strateškog strpljenja, uz istovremenu primenu potrebnih reformi, dajući prioritet održavanju socijalne i političke stabilnosti. Ono što je realnost da bi temeljne civilizacijske tenzije između SAD i Kine mogle bi da nastave u budućnosti, a mogući ishod je, pored ostalog, bifurkacija digitalnog sveta, što bi rezultiralo ozbiljnom zaostajanjem u odnosu na vreme globalizacije. Ovaj za Peking veoma opasan scenario, gde bi Kina bila delimično izolovana od Zapada, naterala bi Peking da značajno više sarađuje sa svojim azijskim susedima.

R. Dalio (2018) smatra da je pogrešno posmatrati Kinu kao komunističku zemlju, već da je, umesto toga, on što se u Kini dešava "državni kapitalizam", u kome se strateški važne kompanije podržavaju da postanu konkurentnije, sa ekonomijom punom preduzetništva, i tržištima koja imaju veliku slobodu. Iako drugačije, Kinom se upravlja slično kao i Singapurom; više od vrha prema dole, s prvenstvenim s ciljem da kompetentni budu stavljeni na mesta donošenja odluka. Ovaj autor smatra da iako je Kina konkurent, i uskoro će biti znatno veća od SAD-a, nije uopšte izvesno da će kapaciteti bilo koje od ove dve zemlje naneti neprocenjive štete drugoj tokom vrlo dugog vremenskog okvira.

\section{ZAKLJUČAK}

Na osnovu projekcija budućih kretanja BDP-a, za SAD, Kinu i EU27 2025-2030, (baziranih na osnovu prethodnih trendova i projekcija MMF-a), odredili smo godinu, 2029, ili pak 2030, u kojoj bi Kina mogla postati najveća svetska ekonomija, prestižući ekonomiju SAD. Time je potvrđena osnovna istraživačka hipoteza budući da promene u ekonomskoj veličini glavnih svetskih aktera, po pravilu, iniciraju posledične geopolitičke konsenkvence. Dodatni doprinos ovog rada je obrada teme koja u našoj akademskog javnosti, i pored brojnih implikacija za Republiku Srbiju, nema praktično nikakvu pažnju, te bi ovo istraživanje moglo da podstakne domaće autore da dodatno razrade datu temu. Uvođenje $\mathrm{u}$ analizu EU27, kao bitnog aktera celokupne geoekonomske jednačine, iako izvesno manje važnog od SAD i Kine, daje radu dodatni značaj.

Ograničenje prezentiranog istraživanja, svakako, podrazumeva fokusiranost na samo jedan (odnosno, dva) pokazatelja koji, iako predstavlja najvažniji indikator ukupne veličine ekonomija, nije dovoljan da bi se sagledao celokupan geo-ekonomski položaj glavnih globalnih aktera. Pored toga, procena budućih kretanja BDP-a kako od strane IMF, tako i od strane autora, uvek je težak zadatak, koji nosi veliki rizik u pogledu preciznosti.

Ono što je, na osnovu svega iznetog jasno jeste to da Peking želi značajniju ulogu u stvaranju inkluzivnog i pravičnijeg globalnog poretka koji je usklađen sa njegovim nacionalnim interesima i pogledima na svet i to može biti realizovano samo ukoliko se ta zemlja, sa novim statusom, vidi kao legitimna u očima drugih nacija. U tom kontekstu, problemi Kine su, pored ostalog, subvencinisanje monopolskih državnih preduzeća i relativno zatvoreno tržište usluga. Dodatni problem je politički legitimitet, odnosno, na Zapadu negativno percipirana autoritarnost režima. Istina, Kina sarađuje sa SAD po pitanjima globalnim klimatskih promena, virusa ebole i nuklearnog programa Severne Koreje, ali je to daleko od dovoljnog (Economy, 2017).

Nasilne tranzicije moći, u kojima rastuće sile (kao danas Kina) svrgavaju sa prestola vodeće sile (SAD) kreirajući novi poredak uz veliki i nasilni prasak, nisu neizbežne. Naime, danas funkcioniše značajan broj opšteprihvaćenih i snažnih međunarodnih institucija (Organizacija ujedinjenih nacija, EU, Svetska trgovinska organizacija), koje su imale relativno veliki uspeh $\mathrm{u}$ amortizovanju kriza i regulisanju odnosa među državama (Igrutinović, 2012, 35).

Dok pojedini autori (Brooks \& Wohlforth, 2008) smatraju da je unipolarni svet i dalje održiv i da će kao takav biti dominantan i u bliskoj budućnosti, čini se da su ubedljivije teze o nadolazećoj multi- 
polarnosti, to jest, više međusobno izbalansiranih centara moći (Gnessoto \& Grevi, 2006). Bipolarni svet bi mogao izrasti kao repriza Hladnog rata (Kina umesto SSSR-a).

Ono što se, verovatno, može očekivati je nastavak trenda disperzije autoriteta i moći na globalnom planu, koji će biti ubrzavan usled pojave novih globalnih igrača. SAD će, skoro izvesno, ove decenije ostati vodeća globalna sila i to zahvaljujući mogućnosti da snažnom diplomatijom i mrežom savezništava uglavnom proguraju svoje prioritete, vojnoj supremaciji i dominirajućem kulturnom obrascu. Dok će EU nastaviti da bude fokusirana na sebe, rast Kine će imati pojačane globalne implikacije, podstičući kretanje ka multipolarnosti ili pak bipolarnosti. Realna je i pojačana uloga države, posebno u ekonomiji. Za razliku od druge polovine XX-og veka, SAD ima limitiranu mogućnost za unilateralne akcije, dok Kina ima velike koristi od trenutnog geopolitičkog aranžmana i globalizacije (Nye, 2014).

Po svemu sudeći, „velika“ igra će nastaviti da se ubrzava tokom 2020-ih. Ekonomija će u velikoj meri odrediti novu geopolitičku konstalaciju. Važan, ali ne i presudan, momenat će biti na kraju ove decenije, kada će Kina, to je sve izvesnije, preuzeti mesto vodeće globalne ekonomije.

\section{ZAHVALNICA}

Rad je napisan u okviru programa istraživanja Instituta za evropske studije i Instituta društvenih nauka za 2020, koji podržava Ministarstvo prosvete, nauke i tehnološkog razvoja.

\section{REFERENCE}

Boxwell, R. (2020). China and the US were never going to live happily ever after, so Trump brokered the best divorce he could. South China Morning Post, 24 Jan, 2020. Retrieved January 25, 2020, from https://www.scmp.com/comment/ opinion/article/3047177/china-and-us-were-never-goinglive-happily-ever-after-so-trump
Brooks, S., \& Wohlforth, W. (2008). World out of Balance: International Relations and the Challenge of American Primacy. Princeton, New Yersey: Princeton University Press.

Centre for Economics and Business Research - CEBR. (2019). World Economic League Table 2020. London, UK: December 2019, 11th edition.

Dollar, D., Huang, Y., \& Yao, Y. (2020). China 2049: Economic challenges of a rising global power. Brookings Institution Press, Retrieved January 31, 2020, from https://www. brookings.edu/wp-content/uploads/2020/01/FP_20200106_ china_2049_dollar_huang_yao.pdf

Dalio, R. (2018). Chinese-American misunderstandings, disputes, and wars. Bridgewater Associates LP, Retrieved July 2, 2019, from https://www.bridgewater.com/resources/ Chinese-American_Misunderstandings_Disputes_and_ Wars.pdf

Economy, E. (2017). Beijing is no champion of globalization. The nyth of Chinese leadership. Foreign Affairs, Retrieved March 13, 2018, from https://www.foreignaffairs.com/articles/ china/2017-01-22/beijing-no-champion-globalization

Edel, C., \& Brands, H. (2019). The real origins of the US-China Cold War. Foreign Policy, Retrieved February 22, 2020, from https://foreignpolicy.com/2019/06/02/the-real-origins-ofthe-u-s-china-cold-war-big-think-communism/

European Parliament. (2019). The EU's position in world trade in figures. Retrieved February 2, 2020, from https://www.europarl.europa.eu/news/en/headlines/ economy/20180703STO07132/the-eu-s-position-in-worldtrade-in-figures-infographic

Eurostat. (2019). November 2019 Euro area international trade in goods surplus $€ 20.7$ bn. Retrieved February 2, 2020, from https://trade.ec.europa.eu/doclib/docs/2013/december/ tradoc_151969.pdf

Fischer, J. (2020). What Kind of Great Power Can Europe Become? Retrieved February 4, 2020, from https://www.projectsyndicate.org/commentary/european-union-great-powerpotential-by-joschka-fischer-2020-01

Gnessoto, N., \& Grevi, G. (2006). The New Global Puzzle: What World for the EU in 2025? Paris, F: Institute for Security Studies.

Huang, C. (2020). If China thinks it's overtaking the US any time soon, here's a wake-up call. South China Morning Post, Retrieved February 3, 2020, from https://www.scmp.com/ week-asia/opinion/article/3006892/if-china-thinks-itsovertaking-us-any-time-soon-heres-wake-call 
Igrutinović, M.(2012). Evropskaspoljnapolitikanadvostrukom koloseku promena: Uticaj novih institucionalnih rešenja i pitanje aktuelne globalne uloge. Pravo i društvo, br. 1/2012. $27-40$.

IMF. (2019). World Economic Outlook Database. October 2019 (IMF staff estimates)

IMF. (2020). World Economic Outlook Database. January 2020. Retrieved February 1, 2020, from https://www.imf.org/ en/Publications/WEO/Issues/2020/01/20/weo-updatejanuary2020

Jankovic, N. (2018). Perspectives of the International Monetary System. Economic Horizons, 20(1), 73-87. doi:10.5937| ekonhor1801075J

Jun, Z. (2020). The Coronavirus Will Not Cripple China's Economy. Projects Syndicate, Retrieved February 11, 2020, from https://www.project-syndicate.org/commentary/ china-coronavirus-three-factors-limit-economic-impactby-shang-jin-wei-2020-01

Kennedy, S. (2018). China will overtake the U.S. economy in less than 15 years, says HSBC, challenging Trump's claim. Bloomberg, Retrieved December 24, 2019, from https://www. bloomberg.com/news/articles/2018-09-25/hsbc-sees-chinaeconomy-set-to-pass-u-s-as-number-one-by-2030

Lane, D. (2019). US-China Relations: Trade Wars or Countervailing Powers? Valdai Club, Retrieved Januuary 31, 2020, from http://valdaiclub.com/a/highlights/us-chinarelations-trade-wars-or-countervailing-po

Mearsheimer, J. (2016). Crouching Tiger: John Mearsheimer on Strangling China \& the Inevitability of War. Death By China, Retrieved March 9, 2018, from https://www.youtube. com/watch?v=yXSkY4QKDlA

Moyo, D. (2020). What Does Europe Have to Offer? Project Syndicate, Retrieved February 9, 2020, from https://www. project-syndicate.org/commentary/european-unionstrengths-for-global-role-by-dambisa-moyo-2020-02

Nye, J. (2014). America's Overrated Decline. Project Syndicate, Retrieved June 16, 2018, from https://www.project-syndicate. org/commentary/declining-public-trust-in-us-institutionsby-joseph-s--nye-2014-10
OECD. (2018). The Long View: Scenarios For the World Economy to 2060. OECD Economic Policy Paper, Paris, July 2018 No. 22. 1-51. doi.org/10.1787/2226583X

PwC. (2017). The World in 2050: The Long View, How will the global economic order change by 2050? PriceWaterhouse Coopers, 1-14.

Stoychev, K. (2020). If You Aren't at the Table, You'll Be on the Menu: Why Europe Seeks a More Independent Role in World Affairs. Valdai Club, Retrieved February 11, 2020, from https://valdaiclub.com/a/highlights/eu-us-if-you-arenot-on-the-table/

Tang, F. (2019). China revises up 2018 GDP after new census, making it easier to double size of economy in 2020. South China Morning Post, Retrieved December 12, 2019, from https://www.scmp.com/economy/china-economy/ article/3038877/china-revises-2018-gdp-after-new-censusmaking-it-easier

Wang, O., \& Behsudi, A. (2019). China s new industrial policy dismissed as 'Made in China 2025' rehash by critics in Washington. South China Morning Post, Retrieved December 24, 2019, from https://www.scmp.com/economy/chinaeconomy/article/3038590/chinas-new-industrial-policydismissed-made-china-2025-rehash

Wangping, Y., \& Xiaolu, L. (2016). An assessment of China's new urbanization level. Economic Horizons, 18(3), 201-213. doi:10.5937/ekonhor1603201W

Yongding, Y. (2018). Has China's Economic growth finally stabilized? Project Syndicate, Retrieved February 9, 2020, from https://www.project-syndicate.org/commentary/ china-prospects-slower-investment-growth-by-yuyongding-2018-01

Yuxian, F., Xiaoling, Y., \& Songke, H. (2014). Electricity investment and economic growth in China. Economic Horizons, 16(2), 85-100. doi:10.5937/ekonhor1402085Y

Primljeno 19. februara 2020, nakon revizije, prihvaćeno za publikovanje 17. avgusta 2020. Elektronska verzija objavljena 19. avgusta 2020. 
Goran Nikolić je viši naučni saradnik Instituta za evropske studije u Beograd. Doktorirao je na Fakultetu za poslovne studije Megatrend univerziteta u Beogradu. Oblasti njegovog naučnog interesovanja su međunarodna ekonomija, monetarna ekonomija, ekonomska istorija, makroekonomija.

Predrag Petrović je viši naučni saradnik na Institutu za društvene nauke, Centru za ekonomska istraživanja u Beogradu. Doktorirao je na Ekonomskom fakultetu Univeziteta u Beogradu. Oblasti naučnog interesovanja su međunarodna ekonomija, makroekonomija, ekonomija životne sredine, primenjena ekonometrija. 


\title{
THE EXPECTED TENDENCIES OF THE GDP OF THE THREE LEADING GLOBAL ECONOMIES IN 2020: IS A REBALANCE OF (GEO)ECONOMIC POWER ARRIVING?
}

\author{
Goran Nikolic ${ }^{1}$ and Predrag Petrovic ${ }^{2}$ \\ 'Institute of European Studies, Belgrade, The Republic of Serbia \\ ${ }^{2}$ Institute of Social Sciences, Center for Economic Research, Belgrade, The Republic of Serbia
}

IMF forecasts a gradual slowdown in the, otherwise strong, growth of the Chinese economy in the first half of the 2020s, and the anemic growth of the Western economies: the US and, especially, the EU27. Given the practical (and symbolic) importance of reaching 'the number one economy' status, the primary objective of the paper is to estimate the GDP (and the GDP PPP) of the observed economies over the next decade. The main contribution and finding of this paper is the estimation of future GDP trends for the US, China and the EU27 in the period 2025-30, based on the previous trends and the IMF 2020-24 projections. China's economy will become globally leading in 2029-2030. The basic research hypothesis is proven, given the fact that a change in the global economic position implies significant geopolitical consequences. Namely, while the US will almost certainly remain the leading global power in the 2020s, with the EU still continuing to focus on itself, China's economic growth will have rising global consequences, fueling the move towards the dispersion of authority. This conclusion is in line with the claims of the majority of the relevant authors who emphasize the increasingly limited possibility of the US unilateral actions.

Keywords: GDP, economic growth, China, the US, EU27, global order

JEL Classification: F2, F50, 047 